\title{
Developing drought stress index for monitoring Pinus densiflora diebacks in Korea
}

\author{
Nanghyun Cho1, Eunsook Kim², Jong-Hwan Lim², Bumsuk Seo ${ }^{3}$ and Sinkyu Kang ${ }^{*^{*}}$ (D)
}

\begin{abstract}
Background: The phenomenon of tree dieback in forest ecosystems around the world, which is known to be associated with high temperatures that occur simultaneously with drought, has received much attention. Korea is experiencing a rapid rise in temperature relative to other regions. Particularly in the growth of evergreen conifers, temperature increases in winter and spring can have great influence. In recent years, there have been reports of group dieback of Pinus densiflora trees in Korea, and many studies are being conducted to identify the causes. However, research on techniques to diagnose and monitor drought stress in forest ecosystems on local and regional scales has been lacking.
\end{abstract}

Results: In this study, we developed and evaluated an index to identify drought and high-temperature vulnerability in Pinus densiflora forests. We found the Drought Stress Index (DSI) that we developed to be effective in generally assessing the drought-reactive physiology of trees. During 2001-2016, in Korea, we refined the index and produced DSI data from a $1 \times 1-\mathrm{km}$ unit grid spanning the entire country. We found that the DSI data correlated with the event data of Pinus densiflora mass dieback compiled in this study. The average DSI value at times of occurrence of Pinus densiflora group dieback was 0.6 , which was notably higher than during times of nonoccurrence.

Conclusions: Our combination of the Standard Precipitation Index and growing degree days evolved and short- and long-term effects into a new index by which we found meaningful results using dieback event data. Topographical and biological factors and climate data should be considered to improve the DSI. This study serves as the first step in developing an even more robust index to monitor the vulnerability of forest ecosystems in Korea.

Keywords: Dieback, Standardized Precipitation Index, Growing degree days, Pinus densiflora, Drought Stress Index

\section{Background}

Owing to climate change, it has been predicted that hotter and longer droughts occur more often around the world (Allen et al. 2010; IPCC 2014). Higher frequency of extreme conditions due to global warming, such as high temperature and drought, can lead to changes in the composition and structure of forests that have high climatic relevance, as well as changes in the spatial distribution of the biome (Mather and Yoshioka 1968;

\footnotetext{
* Correspondence: kangsk@kangwon.ac.kr

'Department of Environmental Science, Kangwon National University,

Chuncheon, Republic of Korea

Full list of author information is available at the end of the article
}

Stephenson 1990; Allen et al. 2015). The phenomenon of climate-related plant dieback in various parts of the world since the 1990s has received much attention (Huang and Anderegg 2012). Other researchers also have reported that the diebacks are related to high temperatures that occurred with drought (Williams et al. 2013; Vicente-Serrano et al. 2014; Camarero et al. 2015).

Recent droughts were accompanied by above-normal temperatures, which was much intense than past droughts (Breshears et al. 2005). For example, in the 1990s, droughts due to the sudden increase in temperature in the northwestern USA caused much damage (Breshears et al. 2005; Williams et al. 2010), and during 2012-2014, the strength

(c) The Author(s). 2020 Open Access This article is licensed under a Creative Commons Attribution 4.0 International License, which permits use, sharing, adaptation, distribution and reproduction in any medium or format, as long as you give appropriate credit to the original author(s) and the source, provide a link to the Creative Commons licence, and indicate if changes were made. The images or other third party material in this article are included in the article's Creative Commons licence, unless indicated otherwise in a credit line to the material. If material is not included in the article's Creative Commons licence and your intended use is not permitted by statutory regulation or exceeds the permitted use, you will need to obtain permission directly from the copyright holder. To view a copy of this licence, visit http://creativecommons.org/licenses/by/4.0/. 
of the drought has increased by $36 \%$ compared to normal drought without having high temperature in California (Griffin and Anchukaitis 2014). High temperatures in Europe in 2003 also caused considerable damage (Breda et al. 2006), and the intensity of the drought was reported to be as severe as that of the intense drought in the 1500s (Williams et al. 2013). Temperature played a major role in the severity of the drought-related damage. We have found that many recent studies emphasized the effects of high temperature occurring with drought (Breshears et al. 2005; Adams et al. 2009; Van Mantgem et al. 2009; Vicente-Serrano et al. 2010; Williams et al. 2013).

The average annual temperature in South Korea has risen by $1.2^{\circ} \mathrm{C}$ over the past 30 years, which is a faster trend of temperature increase than in other regions (Kim et al., 2008; IPCC 2014). Seasonally, winter temperature rose the fastest, while autumn and spring temperatures have exhibited a less-pronounced increase. Precipitation, on the other hand, increased in summer, but fluctuated without a distinct trend in other seasons (Lim 2016). Such a rise in temperature is likely to cause disturbances in the forest ecosystem (Kim et al. 2017a); in particular, rising temperature in winter and spring can have a significant impact on the growth of evergreen conifers, which retain their leaves in these seasons. Although rising winter temperature reduces soil freezing, it can increase evaporation, causing a decrease in available soil water for plants and consequently increasing the likelihood of drought during spring, when growth begins such as leaf sprout and root shoot-out (Kang et al. 2016).

Recently, mass diebacks of Pinus densiflora trees and other evergreen conifers have been reported in Korea, and many studies are being conducted to find out the causes. According to a 2015 land cover map of Korea, Pinus densiflora accounted for approximately $26 \%$ of Korea's forests, which is the highest percentage for a single species. Pinus densiflora have been recognized as one of the important species in maintaining the nation's forest ecosystem, and they are distributed throughout the country and have been used in many ways for a long time, including use as wood (for construction and fuel) and as food (Kim et al. 2017b). The reduction of forests and increase in drought stress due to climate change have been widely expected (Williams et al. 2013), but techniques for diagnosing and monitoring drought stress for healthy forest ecosystems at a local or regional scale have been slow to be developed or applied (Greenwood et al. 2017). This is because most existing droughtmonitoring indices have emphasized meteorological or hydrological aspects with insufficient consideration for the drought stress physiology of trees (Palmer 1965; Guttman 1998; Greenwood et al. 2017).

Recent studies have mentioned much about the importance of NSC (nonstructural carbohydrates) in relation to tree vulnerability and resilience (Tague et al. 2013; Adams et al. 2013; Hartmann and Trumbore 2016). NSC is sugar stored in tree and can perform many functional roles, including transport, metabolism, osmoregulation, defense from insect or herbivore, and buffer for limiting photosynthesis and increasing consumption (Richardson et al. 2013; Fang et al. 2020). NSC is understood to be closely related to the tree dieback, but it is impossible to obtain for a wide spatial and temporal range. So, several studies used models to simulate NSC dynamic and mentioned that temporary carbon storage in the model can act as a key indicator in the death of trees (e.g., Adams et al. 2013; Richardson et al. 2013; Klein and Hoch 2015). Kang et al. (2016) also proposed using the carbon pool (cPool) variable, which is temporary storage for photosynthetic products of plants, as a useful indicator of Pinus densiflora dieback through a biome-biogeochemical cycle (BIOMEBGC) simulation study.

Based on this background, we have established a concept for index development. The index was produced based on precipitation and temperature to account for a change in production and consumption (respiration) that were a major factor in NSC dynamics. Also, the effects of short- and long-term periods were added to the index, considering NSC's short- and long-term patterns.

In this study, we developed a new drought index to monitor and predict stressed Pinus densiflora forests from abnormal climate factors such as high temperature and drought, called the Drought Stress Index, which is calculated from a combination of the Standardized Precipitation Index (SPI) (McKee et al. 1993) and growing degree days (GDD). Both SPI and GDD are indices that have long been used successfully in various fields and have the characteristics of being flexible in terms of time scales. After producing a DSI map of South Korea for the period 2001-2016 at a spatial resolution of $1 \mathrm{~km} \times 1$ $\mathrm{km}$, we compared the relationship of DSI and the distribution of Pinus densiflora mass dieback events.

\section{Materials and methods \\ Development of Drought Stress Index}

Using a process-based model, Kang et al. (2016) simulated the relationship among climate, gross primary productivity (GPP), autotrophic respiration (AR), and cPool of evergreen coniferous trees in the Uljin and Miryang regions in Korea. As a result, the increase in AR due to high temperature and the decrease in GPP caused by drought induced a sudden decline in cPool, which contributed to the dieback events in the two regions. In our study, we assumed that the heat index (HI) associated with AR increase and the SPI with GPP decrease could be useful indicators, based on findings of Kang et al. (2016). The proposed DSI, a simple linear 
combination of SPI and HI, was designed to be high under hot and dry conditions:

$$
\mathrm{DSI}=\alpha \times \mathrm{HI} \_n-\beta \times \operatorname{SPI} \_n
$$

where $\alpha$ and $\beta$ are the coefficients of the temperature and drought indices, respectively, and $n$ is the number of preceding months used in calculating HI and SPI. High temperatures and low precipitation increase plant stress and cause higher DSI values (Table 1 ).

We have identified that there is a long-term pattern in the dynamic in the cPool in addition to the short-term ones. To reflect this, periodicity analysis was performed on time series data from the daily cPool data produced by Kang et al. (2016), which confirmed that there were major short- and long-term cyclic variations with recurrences of 6 and 48 months. In this study, different weighting values $(\alpha, \beta)$ were assigned to investigate how the DSI values varied over SPI, HI, and short- and longterm effects. A total of five models were designed. Model 1 and Model 2 (only considering short-term effect) are only different in temperature and precipitation contribution value $(\alpha, \beta)$ in the calculation of the DSI. Model 1 is applied with the same coefficient of temperature and precipitation. Model 2 focuses more on temperature than precipitation so that high temperatures can have a greater effect on the DSI. Models 3 to 5 (considering both short and long terms) considered long-term effects of 48 months. Model 3 has the same weight of temperature, precipitation, and short- and long-term effects. Model 4 has similar short- and long-term effects, but focuses more on temperature, while Model 5 is more weighted in temperature and short-term effect. Table 2 gives a detailed description of each model.

\section{Standardized Precipitation Index and heat index}

SPI is a proposed index based on the idea that droughts occur when there is insufficient precipitation relative to water demand (McKee et al. 1993). To calculate SPI, we first derive the moving average of the monthly precipitation data at the desired time scale (such as 3,9 , or 12 months), calculate the

Table 1 Category of drought severity per Drought Stress Index (DSI)

\begin{tabular}{ll}
\hline DSI values & DSI category \\
\hline$\geq 2.00$ & Extremely stressed \\
1.50 to 1.99 & Very stressed \\
1.00 to 1.49 & Moderately stressed \\
-0.99 to 0.99 & Near being stressed \\
-1.00 to -1.49 & Moderate condition \\
-1.50 to -1.99 & Good condition \\
$\leq-2.00$ & Very good condition \\
\hline
\end{tabular}

Table 2 Description of the five models

\begin{tabular}{ll}
\hline Model no. & Description \\
\hline Model $1(\mathrm{M} 1)$ & $\mathrm{DSI}=0.5 \times \mathrm{HI} 6-0.5 \times \mathrm{SPI} 6$ \\
Model $2(\mathrm{M} 2)$ & $\mathrm{DSI}=0.7 \times \mathrm{HI} 6-0.3 \times \mathrm{SPI} 6$ \\
Model $3(\mathrm{M} 3)$ & $\mathrm{DSI}=0.5 \times(0.5 \times \mathrm{HI} 6-0.5 \times \mathrm{SPI})$ \\
& $+0.5 \times(0.5 \times \mathrm{HI} 8-0.5 \times \mathrm{SPI} 8)$ \\
Model $4(\mathrm{M} 4)$ & $\mathrm{DSI}=0.5 \times(0.7 \times \mathrm{HI}-0.3 \times \mathrm{SPI})$ \\
& $+0.5 \times(0.7 \times \mathrm{HI} 8-0.3 \times \mathrm{SPI} 8)$ \\
Model $5(\mathrm{M} 5)$ & $\mathrm{DSI}=0.7 \times(0.7 \times \mathrm{HI}-0.3 \times \mathrm{SPI})$ \\
& $+0.3 \times(0.7 \times \mathrm{HI} 8-0.3 \times \mathrm{SPI} 8)$ \\
\hline
\end{tabular}

appropriate monthly probability distribution based on the moving average, obtain the cumulative probability, and estimate the $z$-value corresponding to that of cumulative probability assuming a standard normal distribution. The SPI value indicates the intensity of the drought; the below-zero value signals the beginning of the drought, and the smaller its value, the severe is the drought. In this study, SPI6 and SPI48 were used for DSI estimate based on 6 months and 48 months using the SPI program provided by the U.S. National Drought Mitigation Center (at the University of Nebraska; the software is available for the free download at https:// drought.unl.edu/droughtmonitoring/SPI.aspx).

To consider the effects of temperature, the monthly total GDD was derived from daily average temperature data and used to estimate the DSI. Representing the cumulative value above the threshold temperature, GDD has been used successfully in agriculture since the 1970s to refer to the amount of heat needed for plants to move on to the next development phase in their life cycle (McMaster and Wilhelm 1997). GDD is calculated by

$$
\mathrm{GDD}=\sum_{i=1}^{n}\left(T_{\text {mean }}-T_{\text {base }}\right)
$$

where $T_{\text {mean }}$ is the daily mean temperature, and $T_{\text {base }}$ is the threshold temperature value (the minimum temperature required for growth). The values of $T_{\text {base }}$ vary according to vegetation, and in this study, we set the $T_{\text {base }}$ temperature at $4{ }^{\circ} \mathrm{C}$ for evergreen coniferous forests (Kim et al., 2012). The HI was obtained by the following two steps. First, the GDD was aggregated to monthly GDD (for comparison with the SPI calculated on a monthly basis). Second, the monthly GDD was used in the SPI algorithm to obtain the standardized GDD. We referred to the former as HI.

\section{Temperature and precipitation data processing}

Temperature and precipitation data were downloaded over a period of 17 years (2000-2016), as daily mean temperature $\left({ }^{\circ} \mathrm{C}\right)$ and monthly precipitation $(\mathrm{mm})$ data from weather stations (WS) and automatic weather system (AWS) sites, through the Korea Meteorological 
Administration data-opening portal (https://data.kma.go. $\mathrm{kr} /$ ). Considering the continuity and location of weather data, we chose 357 sites (62 WS and 295 AWS locations) to use in this study (Fig. 1).

To produce a DSI map for the entire country, we used ordinary kriging (one of several methods of spatial interpolation) to convert point weather data into raster data at a spatial resolution of $1 \mathrm{~km} \times 1 \mathrm{~km}$. The variogram required for the kriging interpolation was chosen as the model with the highest $r^{2}$ value among the spherical, exponential, Gaussian, and linear models.
Kriging was performed using such parameter values as nugget, sill, and range calculated from the variogram. Based on the cross-checking results, the RMSE(rootmean-square error) for precipitation showed 51 to 66 $\mathrm{mm}$ from July to September, and a much lower RMSE values were confirmed in other periods. For temperature, RMSE showed a range of 0.6 to $0.9^{\circ} \mathrm{C}$ (Table 3).

\section{Drought events data and statistical analysis}

In Korea, there have been many cases of Pinus densiflora group dieback reported nationwide, but it was difficult to find a summarized event data. For that reason, news




Table 3 Error statistics of $k$-fold cross-validations $(k=30)$ for precipitation $(\mathrm{mm} / \mathrm{month})$ and temperature $\left({ }^{\circ} \mathrm{C} /\right.$ day) interpolations for monthly average for 17 years

\begin{tabular}{llllll}
\hline Month & \multicolumn{2}{l}{ Precipitation } & & \multicolumn{2}{l}{ Temperature } \\
\cline { 2 - 3 } & RMSE & ME & & RMSE & ME \\
\hline Jan & 6.95 & 0.11 & & 0.88 & 0.00 \\
Feb & 15.71 & -0.01 & & 0.73 & 0.01 \\
Mar & 18.76 & 0.09 & & 0.73 & 0.00 \\
Apr & 15.16 & 0.07 & & 0.66 & 0.01 \\
May & 24.39 & 0.23 & & 0.66 & 0.00 \\
Jun & 19.02 & 0.13 & & 0.70 & 0.00 \\
Jul & 51.14 & 0.13 & 0.66 & 0.00 \\
Aug & 66.99 & 0.81 & 0.67 & 0.00 \\
Sep & 56.23 & -0.71 & 0.68 & 0.00 \\
Oct & 11.19 & 0.17 & 0.79 & 0.00 \\
Nov & 4.81 & 0.02 & 0.91 & 0.00 \\
Dec & 7.17 & 0.15 & 0.79 & 0.00 \\
\hline
\end{tabular}

ME mean error, RMSE root-mean-square error

articles about Pinus densiflora group dieback events were collected in the following ways. First, using a major web search engine such as Google, Naver (Korean website), and Daum (Korean website), we collected news articles by entering keywords (tree die-dieback, climate change, drought, high temperature, Pinus densiflora, etc). Then, after removing the overlapping articles, we filtered the data using the following rules: rule 1, check if this article was about Pinus densiflora; rule 2, the dieback of trees that are not caused by disease and harmful insects; rule 3, the region and timing of the group dieback event clearly presented; and rule 4 , it is an official article released by the media, not by personal data. The summarized data was checked once again through expert advice. As a result, the obtained data for the 22 dieback events (Table 4) were compared to DSI results. We tried to divide the intensity of the group dieback damage based on the news article and apply it to the index assessment, but there was a lack of information to quantify all the details. Most news articles contain only approximate information about the region in the province or high-level administrative district (e.g., -si or -gun in Korea) and rough intensity data of dieback. For a more accurate assessment, information of the low-level administrative district (e.g., -ri in Korea) and the number of dieback trees are required, but such data are difficult to find.

The Statistical Package for Social Sciences and the R statistical program were used for basic statistical analysis and data processing, respectively. To evaluate the DSI, we conducted a ranking frequency analysis, which compares rankings at a specific time for the entire period. This method is to rank the DSI values (ordered by the highest DSI value) for each year for a target region and compare the ranking in the tree dieback occurrence year and non-dieback year. If the DSI shows a high ranking for the tree dieback occurrence years, it can be seen as having a high level of explanatory power, and if the ranking is low, it can be considered as a low level of explanatory power. Using the ranking frequency method, the analysis for 16 Pinus densiflora dieback events from 10 regions in Korea was conducted.

\section{Results}

\section{Spatial distribution of Drought Stress Index}

From a combination of SPI and HI, we produced a DSI map of South Korea spanning the 16 years 2001-2016 (Fig. 2a). The results presented were calculated by using the M1 model of the mean DSI map for March-May.

The average DSI in the 2000s was higher than that in the 2010s $(0.301 \pm 0.006$ versus $-0.269 \pm 0.180 ; T$-test, $p<0.001)$. During the entire study period, the average spring temperature was $12.1 \pm 1.1^{\circ} \mathrm{C}$, indicating no significant difference between the 2000s and 2010s. However, in the 2000s, spring precipitation was less than in the $2010 \mathrm{~s}(254.9 \pm 102.2 \mathrm{~mm}$ versus $292.18 \pm 40.1 \mathrm{~mm}$; $p<0.05)$.

In 2009, high temperatures and low precipitation occurred simultaneously, resulting in very high DSI nationwide (Fig. 2b). The southern region of the SPI map showed a low value of -1.2 , while the $\mathrm{HI}$ had a high value of 1.06 for the whole region. In 2009, a massive group dieback of Pinus densiflora was reported across the country, more than one million tree dieback. It was especially severe in the southern region (Gyeongsang, Jeolla province). The average DSI value of nine locations in Gyeongsang province (Gimhae, Miryang, Geoje, Sacheon, Changwon, Gyeongsan, Uljin, Pohang, and Yeongcheon), where Pinus densiflora group dieback events were reported was 1.48 , the highest value during the entire study period.

In 2014, except for the parts of the eastern coast, the overall DSI values were high especially in Gyeonggi (1.07) and western Gangwon (0.84) provinces. In this year, Pinus densiflora mass diebacks were reported in northern Gyeongsangbuk, Gangwon province, where DSI values were relatively low (e.g., Bonghwa, 0.4; Uljin, - 0.3; and Yeongyang, 0.1) (Fig. 2c). In 2015, DSI values were high in the northern region (Gangwon, Gyeonggi, and northern Gyeongsang), and the dieback events were reported in Gangwon and northern Gyeongsang provinces.

\section{Comparison of Drought Stress Index}

Time series data based on five alternative DSI models for the period 2004-2016 were compared for 10 regions where mass dieback events occurred (Fig. 3). An 
Table 4 Dieback events of Pinus densiflora reported in public news media in Korea. Species names were reconfirmed

\begin{tabular}{|c|c|c|c|}
\hline Year & Species & Area & News headline \\
\hline 2003 & Pinus densiflora & Deagu & $\begin{array}{l}\text { The die-back crisis of pine trees in } \\
\text { Apsan mountain, Deagu }\end{array}$ \\
\hline 2007 & Pinus densiflora & Jeonbuk & Pine tree, Unprovoked death \\
\hline 2007 & Pinus densiflora & Gyungbuk (Uljin) & $\begin{array}{l}\text { The sudden death of a 200-year-old pine tree, why did a } \\
\text { drought-resistant pine die? }\end{array}$ \\
\hline 2009 & Pinus densiflora & Southern Korea & $\begin{array}{l}\text { The subtropicalization on the Korean Peninsula is } \\
\text { accelerating - }(5) \text { The vegetation on the Korean } \\
\text { Peninsula is changing }\end{array}$ \\
\hline 2009 & Pinus densiflora & Southern Korea & Pine trees are dying from global warming \\
\hline 2009 & Pinus densiflora & Southern Korea & A dying pine tree on the hot Korean Peninsula \\
\hline 2009 & Pinus densiflora & Gyungsan & 970,000 pine trees withered \\
\hline 2009 & Pinus densiflora & $\begin{array}{l}\text { Gyungbuk (Pohang, Yeongcheon, } \\
\text { Gyeongsan) }\end{array}$ & $\begin{array}{l}\text { Pine tree! It hurt a lot... Southern Gyeongbuk Province } \\
\text { diffuse of die-back phenomena }\end{array}$ \\
\hline 2009 & Pinus densiflora & Jeonnam & $\begin{array}{l}\text { The high risk of pine trees death in Jeonnam Province } \\
\text { due to drought }\end{array}$ \\
\hline 2009 & Pinus densiflora & Gyungnam & $\begin{array}{l}\text { The massive die-back of pine trees in Gyeongnam Province } \\
\text { in due to the stress caused by warming }\end{array}$ \\
\hline 2011 & Pinus densiflora & Gyungnam & Gyeongnam Province pine tree group death \\
\hline 2012 & Pinus densiflora & Daejeon & Dried up Pine tree 'emergency'... ecological hazard signal \\
\hline 2012 & Pinus densiflora & Daegu (Biseul Mt.) & Pine, Pine, 'yellow' pine... Biseul mountain pine tree dried up \\
\hline 2014 & Pinus densiflora & $\begin{array}{l}\text { Gangwon (Samcheok) } \\
\text { Gyungbuk (Yeongyang) }\end{array}$ & $\begin{array}{l}\text { The subtropicalization on the Korean Peninsula is } \\
\text { accelerating -(5)The vegetation on the Korean } \\
\text { Peninsula is changing }\end{array}$ \\
\hline 2014 & Pinus densiflora & Gyungbuk (Uljin) & $\begin{array}{l}\text { About } 200 \text { Geumgang pine tree die-back in Uljin...Forest Service } \\
\text { launch investigation }\end{array}$ \\
\hline 2014 & Pinus densiflora & Gyungbuk (Bonghwa) & Bonghwa County "Save the Pine tree" \\
\hline 2015 & Pinus densiflora & Gyungbuk (Uljin) & 200 pine trees in Pyeonghae-eup died \\
\hline 2015 & Pinus densiflora & $\begin{array}{l}\text { Gyungbk, } \\
\text { Gangwon (Seorak Mt.) }\end{array}$ & $\begin{array}{l}\text { Confirmed the mass deaths of coniferous trees on the } \\
\text { Korean Peninsula 'Climate change is beginning' }\end{array}$ \\
\hline 2015 & Pinus densiflora & $\begin{array}{l}\text { Northern Gyungbuk, } \\
\text { Southern Gangwon }\end{array}$ & $\begin{array}{l}\text { Even if the Geum River water is moved to Boryeong Dam, } \\
\text { the problem cannot be solved The largest damage to } \\
\text { the pine tree after 2009' }\end{array}$ \\
\hline 2016 & Pinus densiflora & Gyungnam (Jiri Mt.) & $\begin{array}{l}\text { High temperatures, droughts and pests... } \\
\text { triple distress of coniferous tree }\end{array}$ \\
\hline 2016 & Pinus densiflora & $\begin{array}{l}\text { Gyungnam (Jiri Mt.), Gyungbuk (Uljin), } \\
\text { Gangwon (Samcheok, Seorak Mt.) }\end{array}$ & Peeled dry bare skin... die-back of Korean coniferous tree \\
\hline 2016 & Pinus densiflora & Gyungbuk (Mungyeong) & Die-back of pine trees, do not know the cause of death \\
\hline
\end{tabular}

analysis of the alternative DSI model results indicated a significant correlation in all cases except for M1:M3 and M2:M3 $(p<0.01$; Table 5). However, DSI values differed in particular years and regions, depending on the weighted contributions of SPI, HI, and short and long terms. For example, during 2010-2011, they differed across the entire region, but only in the northern part of the region during 2014-2016 (Hongcheon, Chuncheon, Seoul, and Pocheon) (Fig. 3). We found that in the northern regions during 2014-2016, when the DSI model (M1) considered only short-term effects, the index was highest in 2015, whereas when the DSI model (M4) considered both short- and longterm effects, it was highest in 2016. Compared to the short- and long-term effects, the changes resulting from SPI and HI weights appeared to be relatively small (Table 5 and Fig. 3).

\section{Relationship between Drought Stress Index and dieback events}

We compared our DSI results with the years of the occurrence of Pinus densiflora diebacks (Fig. 3). In most regions, during 2007-2009, the DSI maintained high values or continued to increase, and Pinus densiflora dieback events were reported in many regions in 2009 when the DSI values were highest. During the period 2010-2013, only one dieback event was reported (in Hongcheon, in 2010), and the DSI gradually decreased to its lowest value, 




reached in 2013. In 2014, the DSI increased again, and mass dieback events happened in Uljin and Bonghwa. However, no dieback events were reported for the northern part of the country in 2014, where DSI was considerably higher compared to the dieback event regions.

We calculated the mean DSI value for the tier when dieback events occurred during 2004-2016 in the 10 target locations and then performed a ranking frequency analysis (Fig. 3 and Table 6). The mean DSI for dieback years was 0.6 , which was greater than the DSI value $(-0.06)$ for non-dieback years $(p<0.001)$. For 8 out of the 14 events, the DSI ranked 1st to 3rd, which is equivalent to $57.1 \%$ of the cumulative percentile, whereas, for the remaining events (5 out of 14), the DSI ranked 4th to 10th (Dieback events were not confirmed for the 11th to 14th rankings.). The event frequency corresponding to the first (1st) DSI rank varies from 2 to 6 depending on the model used. It was higher in the models considering both short- and long-term effects (M3, M4, and M5) and low in the models considering only short-term effects (M1 and M2).

\section{Discussion}

In this study, we have proposed a new index, the DSI, combining the advantages of SPI and HI. Both the temporal flexibility of SPI and the ecological utilization of HI were considered. Our DSI analysis found that in the 2000s, the study area had a higher DSI value compared to the 2010s due to the low spring precipitation. Also, in 2009, when the DSI was highest, a nationwide mass dieback of Pinus densiflora occurred. The drought of 2009 is caused by a simultaneous low SPI and high HI resulting in high DSI values. This is consistent with the recent drought characteristics in which the intensity of drought has increased under conditions of high temperature.

The average DSI value in years when dieback events occurred was higher than that of no-event years. However, the DSI did not show higher explanatory power for some event data as expected. This means that other key factors must be considered in the monitoring of tree dieback events. For example, factors related to topography or biology that could not be explained by the DSI as currently defined, are likely to be key factors affecting tree physiology (Hogg et al. 2013; Lebourgeois et al. 2013). In the previous studies, it is mentioned that older and taller trees can be more vulnerable to drought (Bennett et al. 2015; Rowland et al. 2015), and Kim et al. (2017b) reported that Pinus densiflora in Uljin Sogwang-ri, which lives in high altitude and benefits from high solar radiation, is relatively 


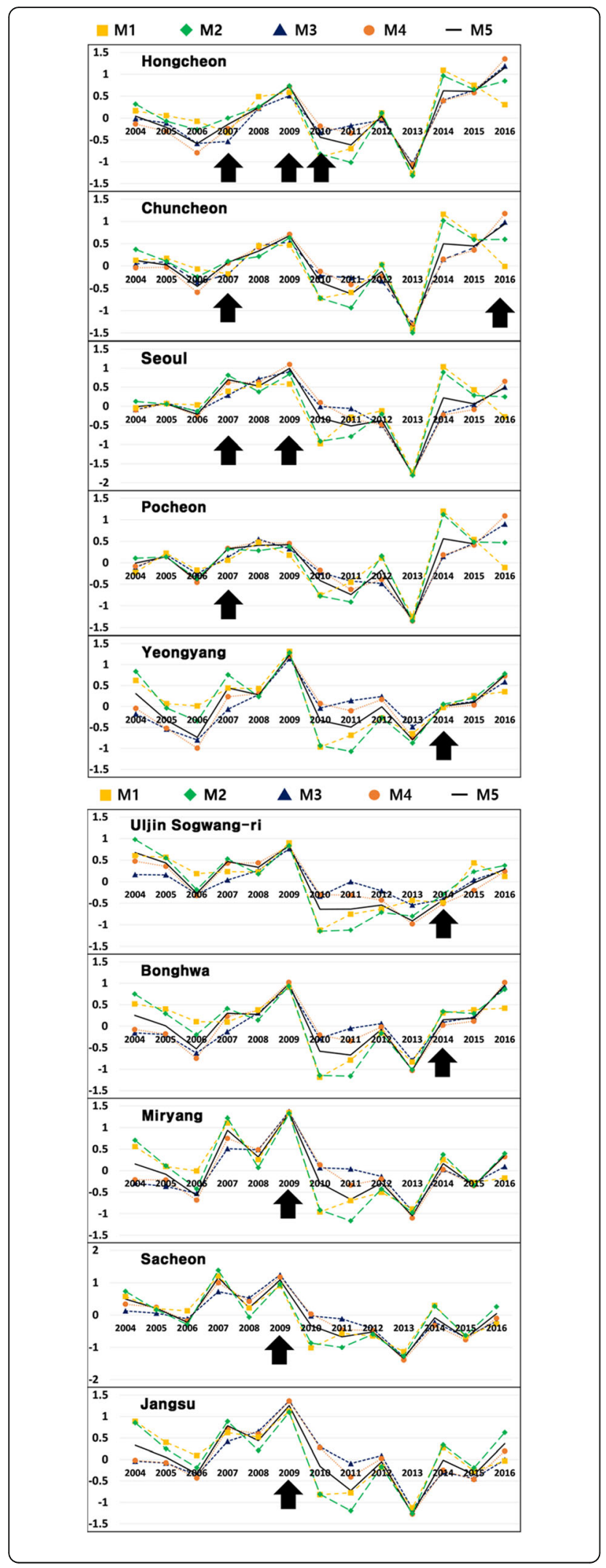

Fig. 3 Drought Stress Index time series for 10 sites (Uljin sogwang-ri, Bonghwa, Miryang, Sacheon, Jangsu, Hongcheon, Chuncheon, Seoul, Pocheon, and Yeongyang). Years of the reported dieback phenomenon are marked with black arrows

vulnerable compared to trees that live in general conditions. The relationship of these temperature and water variables varies depending on local or regional conditions, including geographical and biological factors. The DSI is based on simplifying the climate-productivity-respiration relationship presented by Kang et al. (2016) as an index considering high temperature and drought stress physiology of trees. In this study, only climatic variables were used as the initial stage of a strategic approach to the development of the index, but geographical and biological factors will be added to develop a more useful and effective drought stress index.

Recently, the NSC has received a lot of attention as a key factor of trees dieback and several studies trying to simulate it (Fang et al. 2020). In this process, it was confirmed that NSC has short- and long-term features, respectively in the form of soluble sugar and starch (Richardson et al. 2013). Thus, considering the physiological characteristics of trees, both short- and long-term effects will need to be applied. In addition, considering the long life span of trees, it is necessary to take into account the short but strong drought effects and weak but sustained drought effects. As result, we found that M1 and M2 (only short-term DSI) differed from M3 to M5 (considered both short- and long-term DSI) (Fig. 3). In the analysis of the ranking frequency, the event frequency corresponding to the first (1st) DSI rank was 2 in M1 and M2, whereas M3, M4, and M5 were higher as 6,6 , and 5, respectively. Consequently, the DSI considering both short and long terms appears to be more useful in monitoring dieback events, although more data need to be gathered for its evaluation in the future.

Various forests around the world are being damaged by abnormal weather conditions, and studies have been conducted to understand and predict these phenomena (Huang and Anderegg 2012; Allen et al. 2015). The mechanism for tree dieback has already been revealed.

Table 5 Pearson's correlation coefficient between Drought Stress Index (DSI) models

\begin{tabular}{llllll}
\hline Model & M1 & M2 & M3 & M4 & M5 \\
\hline M1 & 1 & $0.940^{* *}$ & 0.676 & $0.895^{* *}$ & $0.847^{* *}$ \\
M2 & & 1 & 0.705 & $0.884^{* *}$ & $0.926^{* *}$ \\
M3 & & & 1 & $0.933^{* *}$ & $0.902^{* *}$ \\
M4 & & & 1 & $0.959^{* *}$ \\
M5 & & & & 1 \\
\hline${ }^{*} p<0.05^{* *} p<0.01$ & & & &
\end{tabular}


Table 6 Rank analysis for dieback events in the 10 target locations during 2004-2016 (Fig. 3)

\begin{tabular}{lllllllll}
\hline $\begin{array}{l}\text { DSI } \\
\text { rank }\end{array}$ & $\begin{array}{l}\text { DSI } \\
\text { mean }\end{array}$ & \multicolumn{6}{l}{ Frequency by DSI model } & \multicolumn{2}{l}{$\begin{array}{l}\text { Cumulative } \\
\text { conformity (\%) }\end{array}$} \\
\hline 1 & 1.1 & 2 & 2 & 6 & 6 & 5 & 4.2 & 30.0 \\
2 & 0.8 & 2 & 2 & 0 & 1 & 3 & 1.6 & 41.4 \\
3 & 0.7 & 2 & 5 & 2 & 1 & 1 & 2.2 & 57.1 \\
4 & 0.5 & 0 & 1 & 0 & 0 & 0 & 0.2 & 58.6 \\
5 & 0.3 & 0 & 0 & 1 & 1 & 0 & 0.4 & 61.4 \\
6 & 0.2 & 0 & 1 & 0 & 2 & 1 & 0.8 & 67.1 \\
7 & 0.1 & 3 & 2 & 3 & 1 & 3 & 2.4 & 84.3 \\
8 & -0.1 & 2 & 1 & 1 & 1 & 1 & 1.2 & 92.9 \\
9 & -0.2 & 1 & 0 & 1 & 1 & 0 & 0.6 & 97.1 \\
10 & -0.3 & 2 & 0 & 0 & 0 & 0 & 0.4 & 100.0 \\
11 & -0.8 & - & - & - & - & - & - & 100.0 \\
12 & -1.0 & - & - & - & - & - & - & 100.0 \\
\hline
\end{tabular}

For each rank, the mean Drought Stress Index (DSI) was calculated, frequency of dieback events were counted for different models, and then mean frequency was used to calculate cumulative conformity.

(McDowell et al. 2008; Sala et al. 2010). Internal hydraulic failure and carbon starvation, as well as diseases and pathogen from external sources, can operate separately or in combination (McDowell and Sevanto 2010). However, an index and a model that can predict tree dieback considering all these complex relationships could not be found at present. Thus, a strategic method of simplifying and sequentially approaching these complex relationships is necessary. Studies related to the dieback and stress of forest have also taken this approach. Greenwood et al. (2017) developed an index using wood density and specific leaf area with climatic variables to monitor global tree dieback events. Also, Mildrexler et al. (2016) produced a forest stress index based on satellite imagery by a simple combination of land surface temperature and net water balance (precipitation minus evapotranspiration) data. Like those studies, our study is an early step toward developing more useful indices.

Through this study, we revealed the potential of DSI using only climate data. Although the strategy based on the climate-productivity-respiration relationship previously studied for developing such an index seemed useful, we also found that the limitations of the DSI for some events made it very low in explanatory power. Temperate regions exhibit faster trends of temperature increase compared to other regions, and an increase of drought intensity due to high temperature will become more frequent (Kim et al., 2008). Therefore, a new approach to precipitation and temperature relationship is required to determine the intensity and duration of drought (Park et al. 2016; Bhuyan et al. 2017). In that sense, physiological approaches of "the relative importance of drought and high temperature" and "short- and long-term effects" are meaningful. In addition to climate factors, we will consider adding biological factors (such as wood density, age, and biomass) and topographic factors (such as altitude and aspect). Furthermore, we need to collect data on the growth stress of trees (such as tree-ring growth data) and specific dieback events to be used for DSI evaluation. In the future, the increased verification data and understanding of the stress and tree dieback will enable the development of DSI with more rational quantitative diagnosis and predictability.

\section{Conclusion}

Research on how to diagnose and monitor drought stress in the forest ecosystem at local and regional scales has been lacking. Accordingly, we have proposed and evaluated a stress index to identify drought and hightemperature vulnerability of Pinus densiflora forests. By interpolating and combining data on precipitation and temperature, we produced raster data at a spatial resolution of $1 \mathrm{~km} \times 1 \mathrm{~km}$ across South Korea. The precipitation and temperature data were standardized and converted to SPI and HI, and the DSI was calculated through a simple linear combination of SPI and HI. The DSI was compared to and analyzed with dieback event data compiled in this study. As a result, the highest DSI value during the study period was found in Gyeongsang province, where many mass dieback events occurred in 2009. However, for some event data, the DSI value was similar or even lower than those for normal years. In this study, we found a meaningful link between DSI produced by using only climate data and Pinus densiflora dieback event data, thereby confirming the potential use of this new index, the DSI development of DSI with more rational quantitative diagnosis and predictability.

\section{Abbreviations}

DSI: Drought Stress Index; GDD: Growing degree days; SPI: Standardized Precipitation Index

\section{Acknowledgement}

This research was supported by the National Institute of Forest Science's A study of the Pinus densiflora forest conservation/management strategy and technology development for environmental changes and disturbances (FE0100-2019-05-2019).

\section{Authors' contributions}

NC carried out the data collection, performed the analysis, and wrote the manuscript. JHL and EK participated in the design of the study and reviewed the manuscript. BK participated in writing. SK conceived the study and reviewed and edited the manuscript. The authors read and approved the final manuscript.

\section{Funding}

This research was supported by the National Institute of Forest Science's A study of the Pinus densiflora forest conservation/management strategy and technology development for environmental changes and disturbances (FE0100-2019-05-2019). 


\section{Availability of data and materials}

The datasets generated during and/or analyzed during the current study are available from the corresponding author on reasonable request.

\section{Ethics approval and consent to participate}

Not applicable

\section{Consent for publication}

Not applicable

\section{Competing interests}

The authors declare that they have no competing interests.

\section{Author details}

'Department of Environmental Science, Kangwon National University, Chuncheon, Republic of Korea. ${ }^{2}$ Forest Ecology and Climate Change Division, National Institute of Forest Science, Seoul, Republic of Korea. ${ }^{3}$ Karlsruhe Institute of Technology (KIT), Institute of Meteorology and Climate Research/ Atmospheric Environmental Research (IMK-IFU), Garmisch-Partenkirchen, Germany.

Received: 19 February 2020 Accepted: 26 May 2020 Published online: 01 July 2020

\section{References}

Adams HD, Germino MJ, Breshears DD, Barron-Gafford GA, Guardiola-Claramonte M, Zou CB, Huxman TE. Nonstructural leaf carbohydrate dynamics of Pinus edulis during drought-induced tree mortality reveal role for carbon metabolism in mortality mechanism. New Phytol. 2013;197:1142-51.

Adams HD, Guardiola-Claramonte M, Barron-Gafford GA, Villegas JC, Breshears DD, Zou CB, Troch PA, Huxman TE. Temperature sensitivity of droughtinduced tree mortality portends increased regional die-off under globalchange-type drought. Proc Natl Acad Sci. 2009;106:7063-6.

Allen CD, Breshears DD, McDowell NG. On underestimation of global vulnerability to tree mortality and forest die-off from hotter drought in the Anthropocene. Ecosphere. 2015:6(8):129.

Allen CD, Macalady AK, Chenchouni H, Bachelet D, McDowell N, Vennetier M, Kitzberger T, Rigling A, Breshears DD, Hogg EH, Gonzalez P, Fensham R, Zhang Z, Castro J, Demidova N, Lim J-H, Allard G, Running SW, Semerci A, Cobb N. A global overview of drought and heat-induced tree mortality reveals emerging climate change risks for forests. For Ecol Manag. 2010;259(4):660-84.

Bennett AC, McDowell NG, Allen CD, Anderson-Teixeira KJ. Larger trees suffer most during drought in forests worldwide. Nat Plants. 2015;1:15139.

Bhuyan U, Zang C, Menzel A. Different responses of multispecies tree ring growth to various drought indices across Europe. Dendrochronologia. 2017:44:1-8.

Breda N, Huc R, Granier A, Dreyer E. Temperate forest trees and stands under severe drought: a review of ecophysiological responses, adaptation processes and long-term consequences. Ann For Sci. 2006;63:625-44.

Breshears DD, Cobb NS, Rich PM, Price KP, Allen CD, Balice RG, Romme WH, Kastens JH, Floyd ML, Belnap J, Anderson JJ, Myers OB, Meyer CW. Regional vegetation die-off in response to global-change type drought. Proc Natl Acad Sci. 2005;102(42):15144-8.

Camarero JJ, Franquesa M, Sangüesa-Barreda G. Timing of drought triggers distinct growth responses in holm oak: implications to predict warminginduced forest defoliation and growth decline. Forests. 2015;6(5):1576-97.

Fang J, Lutz JA, Shugart HH, Yan X. A physiological model for predicting dynamics of tree stem-wood non-structural carbohydrates. J Ecol. 2020;108:702-18.

Greenwood S, Ruiz-Benito P, Martínez-Vilalta J, Lloret F, Kitzberger T, Allen CD, Kraft NJ. Tree mortality across biomes is promoted by drought intensity, lower wood density and higher specific leaf area. Ecol Lett. 2017;20:539-53.

Griffin D, Anchukaitis KJ. How unusual is the 2012-2014 California drought? Geophys Res Lett. 2014;41(24):9017-23.

Guttman NB. Comparing the Palmer Drought Index and the Standardized Precipitation Index. J Am Water Resour Assoc. 1998;34(1):113-21.

Hartmann $\mathrm{H}$, Trumbore S. Understanding the roles of nonstructural carbohydrates in forest trees - from what we can measure to what we want to know. New Phytol. 2016;211:386-403.

Hogg EH, Barr AG, Black TA. A simple soil moisture index for representing multiyear drought impacts on aspen productivity in the western Canadian interior. Agric For Meteorol. 2013;178:173-82.
Huang C, Anderegg WRL. Large regional drought-induced biomass losses of the rocky mountain aspen forests. Glob Chang Biol. 2012;18:1016-27.

IPCC. In: Team CW, Rachauri RK, Meyer LA, editors. Synthesis report. Conrtibution of Working Group I, II and III to the Firth Assessment Report of the Intergovernmental Panel on Climate Change. Geneva: IPCC; 2014. p. 151.

Kang S, Lim J-H, Kim ES, Cho N. Modelling analysis of climate and soil depth effects on pine tree dieback in Korea using BIOME-BGC. Kor J Agric Forest Meteorol. 2016;18(4):242-52.

Kim BS, Kim BK, Kyung MS, Kim HS. Impact Assessment of Climate Change on Extreme Rainfall and I-D-F Analysis. J Korea Water Res Assoc. 2008; 41(4):379-94.

Kim DW, Park JC, Jang D-H. Analysis of the possibility for drought detection of spring season using SPI and NDVI. Ann Assoc Kor Geograph. 2017a;6(2):165-74.

Kim JB, Kim ES, Lim J-H. Topographic and meteorological characteristics of Pinus densiflora dieback areas in Sogwang-Ri, Uljin. Kor J Agric Forest Meteorol. 2017b;19(1):10-8.

Kim S, Kang S, Lim JH, Chun JH, Sung JH. Regional parameterization of canopy onset models using MODIS and flowering onset data. Ecological Modelling. 2012;247:190-98

Klein T, Hoch $G$. Tree carbon allocation dynamics determined using a carbon mass balance approach. New Phytol. 2015;205:147-59.

Lebourgeois F, Gomez N, Pinto P, Mérian P. Mixed stands reduce Abies alba treering sensitivity to summer drought in the Vosges mountains, western Europe. For Ecol Manag. 2013;303:61-71.

Lim J-H. Climate change-induced dieback of evergreen conifers in Korea and options for adaptation. Seoul: Proceedings of 2016 International Climate Change Adaptation Symposium on Forest Management for Enhancing Resilience to Climate Change; 2016. p. 53-76.

Mather JR, Yoshioka GA. The role of climate in the distribution of vegetation. Ann Assoc Am Geogr. 1968:58:29-41.

McDowell N, Pockman WT, Allen CD, Breshears DD, Cobb N, Kolb T, Plaut J, Sperry J, West A, Williams DG, Yepez EA. Mechanisms of plant survival and mortality during drought: why do some plants survive while others succumb to drought? New Phytol. 2008;178:719-39.

McDowell NG, Sevanto S. The mechanisms of carbon starvation: how, when, or does it even occur at all? New Phytol. 2010:186:264-6.

McKee TB, Doesken NJ, Kleist J. The relationship of drought frequency and duration to time scales. Proc Conf Appl Climatol. 1993:17(22):179-83.

McMaster GS, Wilhelm WW. Growing degree-days: one equation, two interpretations. Agric For Meteorol. 1997;87(87):291-300.

Mildrexler D, Yang Z, Cohen WB, Bell DM. A forest vulnerability index based on drought and high temperatures. Remote Sens Environ. 2016;173:314-25.

Palmer WC. Meteorolofical droughts: U.S. Department of Commerce Weather Bureau Research Pper; 1965. p. 45-58.

Park S, Im J, Jang E, Rhee J. Drought assessment and monitoring through blending of multi-sensor indices using machine learning approaches for different climate regions. Agric For Meteorol. 2016;216:157-69.

Richardson AD, Carbone MS, Keenan TF, Czimczik Cl, Hollinger DY, Murakami P, Schaberg PG, Xu X. Seasonal dynamics and age of stemwood nonstructural carbohydrates in temperate forest trees. New Phytol. 2013;197:850-61.

Rowland L, da Costa ACL, Galbraith DR, Oliveira RS, Binks OJ, Oliveira AAR, Pullen AM, Doughty CE, Metcalfe DB, Vasconcelos SS, Ferreira LV, Malhi Y, Grace J, Mencuccini M, Meir P. Death from drought in tropical forests is triggered by hydraulics not carbon starvation. Nature. 2015;528:119-21.

Sala A, Piper F, Hoch G. Physiological mechanisms of drought-induced tree mortality are far from being resolved. New Phytol. 2010;186:274-81.

Stephenson N. Climatic control of vegetation distribution: the role of the water balance. Am Nat. 1990;135(5):649-70.

Tague CL, McDowell NG, Allen CD. An integrated model of environmental effects on growth, carbohydrate balance, and mortality of Pinus ponderosa forests in the southern Rocky Mountains. PLoS One. 2013;8(11).

Van Mantgem PJ, Stephenson NL, Byrne JC, Daniels LD, Franklin JF, Fulé PZ, Harmon ME, Larson AJ, Smith JM, Taylor AH, Veblen TT. Widespread increase of tree mortality rates in the western United States. Science. 2009:323:521-4.

Vicente-Serrano SM, Begueria S, Lopez-Moreno II. A multi-scalar drought index sensitive to global warming: the standardized precipitation evapotranspiration index (SPEI). J Clim. 2010;23:1696-718.

Vicente-Serrano SM, Lopez-Moreno Jl, Begueria S, Lorenzo-Lacruz J, SanchezLorenzo A, Garcia-Ruiz JM, Azorin-Molina C, Moran-Tejeda E, Revuelto J, Trigo $\mathrm{R}$, Coelho F, Espejo F. Evidence of increasing drought severity caused by temperature rise in southern Europe. Environ Res Lett. 2014;9(4):044001. 
Williams AP, Allen CD, Macalady AK, Griffin D, Woodhouse CA, Meko DM, Swetnam TW, Rauscher SA, Seager R, Grissino-Mayer HD, Dean JS, Cook ER,

Gangodagamage C, Cai M, McDowell NG. Temperature as a potent driver of regional forest drought stress and tree mortality. Nat Clim Chang. 2013;3:292-7.

Williams AP, Allen CD, Millar Cl, Swetnam TW, Michaelsen J, Still CJ, Leavitt SW.

Forest responses to increasing aridity and warmth in the southwestern

United States. Proc Natl Acad Sci. 2010;107:21298-4.

\section{Publisher's Note}

Springer Nature remains neutral with regard to jurisdictional claims in published maps and institutional affiliations.

Ready to submit your research? Choose BMC and benefit from:

- fast, convenient online submission

- thorough peer review by experienced researchers in your field

- rapid publication on acceptance

- support for research data, including large and complex data types

- gold Open Access which fosters wider collaboration and increased citations

- maximum visibility for your research: over $100 \mathrm{M}$ website views per year

At $\mathrm{BMC}$, research is always in progress.

Learn more biomedcentral.com/submissions 